\title{
Bilirubin and Atherosclerotic Diseases
}

\section{VÍTEK ${ }^{1}$}

${ }^{1}$ Fourth Department of Internal Medicine and Institute of Medical Biochemistry and Laboratory Diagnostics, First Faculty of Medicine, Charles University, Prague, Czech Republic

Received October 25, 2016

Accepted December 14, 2016

\section{Summary}

Bilirubin is the final product of heme catabolism in the systemic circulation. For decades, increased serum/plasma bilirubin levels were considered an ominous sign of an underlying liver disease. However, data from recent years convincingly suggest that mildly elevated bilirubin concentrations are associated with protection against various oxidative stress-mediated diseases, atherosclerotic conditions being the most clinically relevant. Although scarce data on beneficial effects of bilirubin had been published also in the past, it took until 1994 when the first clinical study demonstrated an increased risk of coronary heart disease in subjects with low serum bilirubin levels, and bilirubin was found to be a risk factor for atherosclerotic diseases independent of standard risk factors. Consistent with these results, we proved in our own studies, that subjects with mild elevation of serum levels of unconjugated bilirubin (benign hyperbilirubinemia, Gilbert syndrome) have much lower prevalence/incidence of coronary heart as well as peripheral vascular disease. We have also demonstrated that this association is even more general, with serum bilirubin being a biomarker of numerous other diseases, often associated with increased risk of atherosclerosis. In addition, very recent data have demonstrated biological pathways modulated by bilirubin, which are responsible for observed strong clinical associations.

\section{Key words}

Bilirubin - Atherosclerosis - Benign hyperbilirubinemia • Cardiovascular diseases • Gilbert syndrome

\section{Corresponding author}

L. Vítek, Institute of Medical Biochemistry and Laboratory Diagnostics, First Faculty of Medicine, Charles University, $\mathrm{Na}$ Bojišti 3, Prague, Czech Republic. E-mail: vitek@cesnet.cz

\section{Introduction}

Serum bilirubin, for decades considered an ominous sign of an underlying liver disease and unfavorable prognostic factor, seems to affect biological processes in much wider consequences. Bilirubin, formed primarily from senescent red blood cells via the heme catabolic pathway in the reticulo-endothelial system has several unique biological properties. Due to a system of conjugated double bonds within its molecule, it is a potent endogenous antioxidant (Stocker et al. 1987). It is also a non-competitive inhibitor of oxidative as well as protein phosphorylation (Hansen et al. 1996) with widespread biological effects, including energy homeostasis, enzyme and membrane functions, protein synthesis, RNA/DNA metabolism, and immunologic mechanisms (Hansen et al. 1996). Quite recently, bilirubin was demonstrated to be a natural PPAR $\alpha$ ligand (Stec et al. 2016) further enlarging its potential to affect metabolic functions in a human body (Hinds et al. 2016).

This review follows our previous review papers on this topic (Lin et al. 2010, Schwertner and Vitek 2008, Vitek 2012, Vitek and Ostrow 2009, Vitek and Schwertner 2007, Wagner et al. 2015) with the main focus on the contribution of our group to the clinical research of bilirubin and atherosclerosis, demonstrating also further perspectives of this interesting molecule.

\section{Bilirubin as a potent endogenous antioxidant}

However, the whole story started much earlier than in 90's. A potential physiological role for bilirubin was proposed as early as 1954 by Bernhard et al., who had shown that small quantities of bilirubin had been able 
to prevent the oxidation of vitamin A and unsaturated fatty acids. Similar results on the inhibition polyunsaturated fatty acid oxidation by bilirubin were published decades later by Japanese investigators (Onishi et al. 1971) as well as in a landmark study by Stocker et al. (1987). Also additional studies confirmed huge antioxidant potential of bilirubin, such as that of Wu et al. (1994) who demonstrated that bilirubin is 20-times more effective in preventing LDL oxidation than Trolox, a vitamin $\mathrm{E}$ analogue. In addition, it was demonstrated in another study that $10 \mathrm{nmol} / 1$ of bilirubin, exerting its antioxidant activities in so-called biliverdin-bilirubin redox cycle, protects against almost 10,000-fold higher concentrations of $\mathrm{H}_{2} \mathrm{O}_{2}$ (Baranano et al. 2002).

\section{Bilirubin as an anti-atherogenic molecule - lessons from the clinical studies on cardiovascular diseases}

In 1994, Schwertner et al. were the first researchers who reported in their large epidemiological study on almost 900 males a negative association between fasting serum bilirubin concentrations and ischemic heart disease (IHD). The strength of this association was similar to that of smoking, systolic blood pressure, and HDL-cholesterol. Early after publication of this report, we have initiated a retrospective study on subjects with Gilbert syndrome (also known as benign hyperbilirubinemia, characterized with mild elevation of unconjugated bilirubin in the absence of any underlying liver disease and/or hemolysis) (Vitek et al. 2002). Although the cohort was small $(\mathrm{n}=50)$, the individuals with benign hyperbilirubinemia had a prevalence rate for IHD of $2 \%$ compared to $12.1 \%$ for the general population. The study was switched to prospective fashion and subjects were followed for the next 3 years. During this period of follow-up virtually no case of IHD was diagnosed in the population with Gilbert syndrome as compared to significantly higher predicted 3-year incidence of IHD in the group without Gilbert syndrome $(3.1 \%)$. These data are highly clinically relevant since the prevalence of Gilbert syndrome is between $2-12 \%$ in the general population, in the Czech Republic being $6.7 \%$ (our unpublished data). Apart from being protected from atherosclerotic (and some other oxidative stressmediated diseases), subjects with Gilbert syndrome are at higher risk of development of the pigment gallstone disease, and more importantly, clinically relevant drug intractions. These are linked to Gilbert syndrome genotype (mostly UGT1A1*28 allele homozygosity in Caucasian population) having twice as high prevalence compared to Gilbert syndrome phenotype due to low penetrance of this mutation.

A year later, we performed a meta-analysis of eleven studies covering male subjects, which demonstrated a strong negative relationship between serum bilirubin levels and severity of atherosclerosis in men $(\mathrm{p}<0.0001) \quad$ (Novotny and Vitek 2003). Non-parametric, regression, and stratified analyses all reliably demonstrated a negative relationship between serum bilirubin concentrations and atherosclerotic diseases. A serum bilirubin level of $10.0 \mu \mathrm{mol} / 1$ was found to be the cut-point for discrimination of cardiovascular risk in analyzed men (for physiological serum bilirubin concentrations see Table 1). Interestingly, hyperbilirubinemia due to underlying liver function (reflected by elevated liver function enzymes) deterioration did not result in protection against cardiovascular diseases (Novotny and Vitek 2003) and was shown also later to eliminate protective effects of bilirubin on all-cause mortality (see also below) (Fulks et al. 2009). Thus this fact must be taken into consideration when assessing the individual risk of a patient - and also accounts for U-shape relationship between serum bilirubin and cardiovascular diseases observed in some studies (Breimer et al. 1995). Data from our meta-analysis were confirmed also in a recent metaanalytic study in both men and women (Kunutsor et al. 2015), although another one revealed only a non-significant protective trend for increased bilirubin concentrations (Stender et al. 2013).

Table 1. Physiological levels of serum bilirubin.

Serum bilirubin $(\mu \mathrm{mol} / \mathrm{l})$

$\begin{array}{lc}\text { Physiological range } & 3-17 \\ \text { Czech population } & 9.8 *[8-12.4] \\ \text { Gilbert syndrome } & 17-86\end{array}$

* Data represent median and IQ range and are based on our unpublished data of 717 subjects retrieved from WHO MONICA study.

We were also interested, whether serum bilirubin might be implicated in manifestation of premature coronary atherosclerosis. For that reason, we have studied 79 patients with premature myocardial infarction (defined 
as its manifestation prior $<45$ and $<55$ years of age in males and females, respectively). Although these patients were found to also have lower bilirubin levels, to our surprise, the correlation of premature coronary artery disease with serum bilirubin was much milder that of patients with chronic IHD suggesting that other exogenous factors (e.g. smoking) as well as specific genetic predictors seem to be more important in manifestation of premature atherosclerosis (unpublished data).

We also put our focus on possible relationship between clinical markers of atherosclerotic lesions and systemic bilirubin concentrations. A cohort of 111 healthy men, 38 of whom had Gilbert syndrome, were analyzed for presence of carotid atherosclerosis, carotid intima-medial thickness of $0.8 \mathrm{~mm}$ being set as a marker of clinically relevant atherosclerosis (Vitek et al. 2006). Those subjects having mild elevation of serum bilirubin levels (benign hyperbilirubinemia) had very low prevalence of carotid atherosclerosis, and the negative relationship was significant even after adjustment for other risk factors (Vitek et al. 2006). Interestingly, the anti-atherogenic association of serum bilirubin was much more evident in older subjects ( $>48$ years), and it was even possible to predict that the development of clinically relevant carotid atherosclerosis in subjects with Gilbert syndrome is postponed by almost 25 years. Our data are consistent also with majority of published reports on the association between serum bilirubin and peripheral artery disease. To cite at least one of the most important studies (in complex reviewed by Schwertner and Vitek 2004); in 2008, Perlstein et al. published a retrospective study on more than 7,000 adults from the National Health and Nutrition Examination Survey (NHANES) on this association. After adjustment for possible confounding factors, each $0.1 \mathrm{mg} / \mathrm{dl}(1.7 \mu \mathrm{mol} / \mathrm{l})$ increase in serum bilirubin level was associated with $6 \%$ reduction in the odds of having peripheral atherosclerosis.

Taking into account the above given data on atheroprotective effects of bilirubin, it is not surprising that identical negative correlations are present also for other diseases commonly associated with accelerated atherosclerosis. In fact, this is true for diabetes mellitus (for comprehensive review on the relationships between bilirubin and diabetes see Vitek (2012)). In our own, so far unpublished study on more than 200 patients with type 2 diabetes mellitus and almost 500 age-matched healthy controls, we were able to demonstrate much lower serum bilirubin levels in both male and female diabetic patients, and each micromolar increase of serum bilirubin was associated with substantial decrease of the odds of developing diabetes (Jiraskova 2011a). Our data are consistent with the majority of published data including a recent systematic review and meta-analysis demonstrating negative association between systemic bilirubin levels and type 2 diabetes mellitus, as well as metabolic syndrome (Nano et al. 2016). It is interesting to note that serum bilirubin levels were negatively associated with markers of glucose metabolism also in patients with type 1 diabetes mellitus (Mianowska et al. 2014). It is then logical, that the same negative relationship was found for serum bilirubin levels and obesity (Andersson et al. 2009), reviewed in Wagner et al. (2015), and beneficial role of bilirubin for serum lipid metabolism has also been consistently demonstrated (Bulmer et al. 2013). These associations are complex and involve negative association of serum bilirubin with total and LDL cholesterol and positive association with HDL cholesterol (Bulmer et al. 2013). In this respect, it is interesting to note that HDL is a potent binding molecule for bilirubin (apart from albumin) (Vitek and Ostrow 2009).

\section{Bilirubin as an anti-atherogenic molecule - lessons from the clinical studies on diseases associated with increased risk of atherosclerosis}

A wide array of various pathogenically different diseases is associated with increased risk of atherosclerosis. We have systematically studied some of them with remarkable and consistent findings of negative associations between the manifestation of these diseases and systemic bilirubin levels.

We studied a cohort of more than 50 patients with a Fabry disease, an X-linked metabolic disorder, caused by deficiency of the lysosomal enzyme $\alpha$-galactosidase A resulting in accumulation of glycosphingolipids in endothelial cells and other tissues and organs (Zarate and Hopkin 2008). The majority of Fabry disease complications results from a vasculopathy associated with a progressive damage of the heart and vessels resulting in accelerated IHD (Anastasakis et al. 2013). In our study, Fabry disease was associated with significantly lower serum bilirubin levels and markers of increased oxidative stress. Interestingly, specific enzyme replacement therapy normalized both serum bilirubin levels as well as total serum antioxidant capacity suggesting that low serum bilirubin levels in this disease 
are due to increased oxidative stress and enhanced consumption of endogenous antioxidants (Jiraskova et al. 2011b).

We were able to demonstrate similar associations for a variety of systemic autoimmune diseases. This was true for patients with Crohn's disease (Lenicek et al. 2014), an inflammatory bowel disease often associated with increased cardiovascular risk (Wu et al. 2016). In this study, apart from much lower bilirubin concentrations in Crohn's disease patients, Gilbert syndrome genotype (UGT1A1*28 homozygosity) was associated with a significant delay in Crohn's disease manifestation (Lenicek et al. 2014).

Similarly, in our another study on patients with systemic lupus erythematosus (SLE), a systemic autoimmune disease associated with markedly increased risk of cardiovascular diseases (Lewandowski and Kaplan 2016), a significantly lower bilirubin levels were observed in these patients (Schwertner and Vitek 2004, Vitek et al. 2010a). Furthermore, each micromolar decrease in serum bilirubin was associated with a $37 \%$ increase in the odds for a positive SLE status. Simultaneously, the odds of unconjugated hyperbilirubinemia characteristic for Gilbert syndrome were more than four times lower in SLE patients (Schwertner and Vitek 2004, Vitek et al. 2010a).

Similar and consistent results were found also on the relationship between serum bilirubin and the risk of rheumatoid arthritis in our clinical trial (Schwertner and Vitek 2004) and a study by Fishman et al. (2010), as well as between serum bilirubin and the risk of Wegener granulomatosis (our unpublished data), both autoimmune diseases being markedly associated with increased cardiovascular risk (Liao 2017, Faurschou et al. 2009, respectively).

Interestingly, similar negative association between serum bilirubin was observed also in patients with manifesting schizophrenia, a psychiatric disease linked to increased cardiovascular risk (Davidson 2002). In this study, the odds for unconjugated hyperbilirubinemia $>17 \mu \mathrm{mol} / 1$ characteristic for Gilbert syndrome were four times lower in schizophrenic patients compared to the control population. Furthermore, each micromolar increase in serum bilirubin was associated with a $19 \%$ decrease in the odds for schizophrenia status (Vitek et al. 2010b).

Finally, substantially lower serum bilirubin levels were detected in patients with colorectal cancer; each micromolar decrease in serum bilirubin being associated with a significant $7 \%$ increase of colorectal cancer risk (Jiraskova et al. 2012). The link between colon cancer and atherosclerosis is not direct, but colon cancer is associated with metabolic syndrome and atherogenic lipid profile (Liu et al. 2010), both condition deeply involved in the process of atherogenesis.

To completely disclose the potential impact of systemic bilirubin levels on manifestation of various systemic diseases, studies by other authors should be mentioned. These include chronic obstructive pulmonary diseases (COPD) (Horsfall et al. 2011), psoriasis (Balta et al. 2014), multiple sclerosis (Peng et al. 2011), osteoporosis (Bian et al. 2013), and preeclampsia (Breslin et al. 2013). Surprisingly, all these conditions have been associated with an increased cardiovascular disease morbidity (Anagnostis et al. 2009, Coumbe et al. 2014, Ghoorah et al. 2013, Christiansen et al. 2010, McDonald et al. 2013) indicating a possible common role of bilirubin in protection against these diseases.

\section{Relationship between serum bilirubin and markers of oxidative stress and inflammation}

To explore what is the underlying link between bilirubin and decreased risk of cardiovascular diseases, we and others have clinically investigated the relationship of the markers of oxidative stress, inflammation and vascular dysfunction.

In one of our clinical studies on Gilbert syndrome subjects, we demonstrated in these hyperbilirubinemic individuals significantly lower serum levels of pentosidine and $\mathrm{N}^{\varepsilon}$-carboxymethyl lysine, both belonging to advanced glycation end-products (AGEs), being positively associated with endothelial dysfunction, progression of atherosclerosis (Peppa et al. 2004) and diabetes (Turk et al. 2003). Levels of both AGEs remained substantially lower even after adjustment for selected vascular risk and other modifying factors (Kalousova et al. 2005). In another study on subjects with Gilbert syndrome we reported markedly lower urinary excretion of biopyrrins (Vitek et al. 2007a), tripyrrolic compounds produced by bilirubin oxidation under conditions of increased oxidative stress, including cardiovascular diseases (Hokamaki et al. 2004). These data were fully in line with our additional observation of negative association of serum bilirubin with systemic levels of 7-oxocholesterol and 7 $\beta$-hydroxycholesterol (Vitek et al. 2013), both oxysterols being strongly correlated with vascular diseases (Vejux and Lizard 
2009). In this study, serum bilirubin was also significantly correlated with total plasma peroxyl scavenging activity. It is noteworthy to mention, that we observed similar positive association of total serum antioxidant capacity (measured in $\operatorname{ABTS}^{\circledR}$ assay) also in our original cohort of Gilbert syndrome individuals (Vitek et al. 2002). An addition of bilirubin to the serum with a defined total antioxidant capacity led to a significant elevation of this parameter in response to a progressive increase of the bilirubin concentration. Interestingly, this increase was much higher than might be expected from stochiometric calculations supporting the existence of bilirubin/biliverdin redox cycle or another antioxidant defense amplifying mechanism (Vitek et al. 2002).

The same method for determination of total antioxidant capacity was applied also to much larger population of healthy subjects $(n=288)$. Subjects in the lowest bilirubin quartile had apparently lower serum total antioxidant capacity as compared to subjects with highest serum bilirubin $(\mathrm{P}<0.0001)$. Importantly, subjects with the lowest serum bilirubin had also distinctly higher serum hsCRP levels as compared to subjects in the highest bilirubin quartile (Vitek et al. 2007b). The same relationship was reported also by other authors (Hwang et al. 2011). It should also be noted, that all these observations may account for improved endothelial function of subjects with mild elevation of unconjugated bilirubin, either in the form of Gilbert syndrome (Maruhashi et al. 2012), or iatrogenically induced (Dekker et al. 2011).

\section{Other aspects of bilirubin protective action}

There are many other possible aspects how bilirubin might exert its protective action, whose description is beyond the scope of this paper and which were subject of recent reviews. These include the beneficiary role of bilirubin on lipid metabolism (Bulmer et al. 2013), its anti-aging effects (Wallner et al. 2013a), potential anti-thrombotic effects via inhibition of platelet activation (Kundur et al. 2015), strong immunosupressive activities of bilirubin effects acting on almost all levels of both innate as well as adaptive immune response (Jangi et al. 2013), or even anti-mutagenic and anti-genotoxic effects of bilirubin (Molzer et al. 2013, Wallner et al. $2013 \mathrm{~b}$ ). As already mentioned above, bilirubin is even likely to activate PPAR $\alpha$ nuclear receptors (Stec et al. 2016) further enlarging its potential to affect metabolic functions in a human body (Hinds et al. 2016) and possibly accounting for many of the clinical observations.

\section{Bilirubin and overall mortality}

Based on strong negative clinical associations described above, it is not surprising that systemic bilirubin concentrations are related cardiovascular, as well as all-cause mortality. Indeed, a large number of epidemiological studies investigating relationship of bilirubin and mortality have been reported during the last decade (for comprehensive review of this topic see Wagner et al. 2015). Among the largest studies was that by Fulks et al. (2009), who included nearly two million health insurance applicants and investigated all-cause mortality associated with bilirubin concentrations. In this study, lower bilirubin levels were associated with significantly increased mortality. Significant negative association of serum bilirubin concentrations and overall mortality was observed also in a recent US NHANES study on older adults above 60 years of age (Ong et al. 2014). And finally, in their large studies Horsfall et al. (2012) confirmed enhanced mortality rates in subjects with lower bilirubin concentrations, whereas subjects with Gilbert syndrome had twice as low mortality compared to normobilirubinemic subjects (Horsfall et al. 2013).

\section{Could bilirubin be a therapeutic target?}

This is a question intensively studied over the last years, and comprehensively reviewed in recent literature (McCarty 2007). Based on data described in this paper it is important to emphasize, that even tiny (i.e. single units of micromoles/l) elevations of systemic (and probably also only topical) concentrations of bilirubin can produce substantial benefit resulting in significantly decreased risk of many oxidative stress-mediated diseases. Such elevation might be achieved by induction of heme oxygenase (Muchova et al. 2007), the key enzyme degrading heme to biliverdin/bilirubin, or inhibition of bilirubin UDPglucuronosyl transferase (UGT1A1), the key enzyme responsible for bilirubin conjugation in the liver tissue (Dekker et al. 2011). It is also likely that many drugs commonly used in clinical medicine may exert these activities and result in mild elevation of serum bilirubin levels, statins being such an example (Vitek et al. 2011). Moreover, other tetrapyrrolic molecules related to 
bilirubin/biliverdin molecular structure occurring commonly in nature may exert similar effect as bilirubin. Such an example might be phycocyanobilin, a linear tetrapyrrolic molecule occurring in edible algae, which, at least experimentally, was demonstrated to delay progression of atherosclerosis activating several atheroprotective mechanisms (Strasky et al. 2013).

\section{Conclusion}

Increasing pile of evidence suggests that bilirubin is a highly bioactive molecule having deep impact on prognosis of cardiovascular and other diseases. Due to recent discoveries of bilirubin binding to nuclear receptors (besides PPAR $\alpha$, aryl hydrocarbon receptor (AhR) is another typical nuclear bilirubin receptor), and taking into account its production in remote organs, bilirubin behaves in certain circumstances as a hormone. It is interesting to note that similar endocrine effects have been recently discovered for bile acids, also considered for long time negligible molecules in this regard (Vitek and Haluzik 2016). Apart from known antioxidant and other biological activities of bilirubin it seems likely that its "endocrine" effects importantly contribute to healthpromotion and may account for many clinical observations. Although we still do not know all the molecular mechanisms behind its biological action, bilirubin becomes an important prognostic marker and potential therapeutic target.

\section{Conflict of Interest}

There is no conflict of interest.

\section{Acknowledgements}

Supported by Ministry of Health of the Czech Republic, grant Nr. 15-28895A, and PRVOUK 4102280002 from the Czech Ministry of Education, and RVO VFN64165 from the Czech Ministry of Health. All rights reserved.

\begin{abstract}
Abbreviations
AGEs, advanced glycation-end products; HDL, high density lipoprotein; hsCRP, highly sensitive C-reactive protein; IHD, ischemic heart disease; LDL, low density lipoprotein; SLE, systemic lupus erythematosus; UGT1A1, bilirubin UDP-glucuronosyl transferase.
\end{abstract}

\section{References}

ANAGNOSTIS P, KARAGIANNIS A, KAKAFIKA AI, TZIOMALOS K, ATHYROS VG, MIKHAILIDIS DP: Atherosclerosis and osteoporosis: age-dependent degenerative processes or related entities? Osteoporos Int 20 : 197-207, 2009.

ANASTASAKIS A, PAPATHEODOROU E, STERIOTIS AK: Fabry disease and cardiovascular involvement. Curr Pharm Des 19: 5997-6008, 2013.

ANDERSSON C, WEEKE P, FOSBOL EL, BRENDORP B, KOBER L, COUTINHO W, SHARMA AM, VAN GAAL L, FINER N, JAMES WP, CATERSON ID, RODE RA, TORP-PEDERSEN C; SCOUT EXECUTIVE STEERING COMMITTEE; SCOUT INVESTIGATORS: Acute effect of weight loss on levels of total bilirubin in obese, cardiovascular high-risk patients: an analysis from the lead-in period of the Sibutramine Cardiovascular Outcome trial. Metabolism 58: 1109-1115, 2009.

BALTA S, BALTA I, MIKHAILIDIS DP, OZTURK C, DEMIRKOL S, CELIK T, KILIC S, DEMIR M, IYISOY A: Bilirubin levels and their association with carotid intima media thickness and high-sensitivity C-reactive protein in patients with psoriasis vulgaris. Am J Clin Dermatol 15: 137-142, 2014.

BARANANO DE, RAO M, FERRIS CD, SNYDER SH: Biliverdin reductase: a major physiologic cytoprotectant. Proc Natl Acad Sci USA 99: 16093-16098, 2002.

BERNHARD K, RITZEL G, STEINER KU: Uber eine biologische bedeutung der gallenfarbstorre: bilirubin und biliverdin als antioxydantien für das vitamin A und die essentiellen fetsauren. Helv Chim Acta 37: 306-313, 1954.

BIAN LQ, LI RZ, ZHANG ZY, JIN YJ, KANG HW, FANG ZZ, PARK YS, CHOI YH: Effects of total bilirubin on the prevalence of osteoporosis in postmenopausal women without potential liver disease. J Bone Miner Metab 31: 637-643, 2013.

BREIMER LH, WANNAMETHEE G, EBRAHIM S, SHAPER AG: Serum bilirubin and risk of ischemic heart disease in middle-aged British men. Clin Chem 41: 1504-1508, 1995. 
BRESLIN E, KAUFMANN A, QUENBY S: Bilirubin influences the clinical presentation of pre-eclampsia. Eur $J$ Obstet Gynecol Reprod Biol 170: 111-113, 2013.

BULMER AC, VERKADE HJ, WAGNER KH: Bilirubin and beyond: a review of lipid status in Gilbert's syndrome and its relevance to cardiovascular disease protection. Prog Lipid Res 52: 193-205, 2013.

CHRISTIANSEN CF, CHRISTENSEN S, FARKAS DK, MIRET M, SORENSEN HT, PEDERSEN L: Risk of arterial cardiovascular diseases in patients with multiple sclerosis: a population-based cohort study. Neuroepidemiology 35: 267-274, 2010.

COUMBE AG, PRITZKER MR, DUPREZ DA: Cardiovascular risk and psoriasis: beyond the traditional risk factors. Am J Med 127: 12-18, 2014.

DAVIDSON M: Risk of cardiovascular disease and sudden death in schizophrenia. J Clin Psychiatry 63 (Suppl 9): 5-11, 2002.

DEKKER D, DORRESTEIJN MJ, PIJNENBURG M, HEEMSKERK S, RASING-HOOGVELD A, BURGER DM, WAGENER FA, SMITS P: The bilirubin-increasing drug atazanavir improves endothelial function in patients with type 2 diabetes mellitus. Arterioscler Thromb Vasc Biol 31: 458-463, 2011.

FAURSCHOU M, MELLEMKJAER L, SORENSEN IJ, SVALGAARD THOMSEN B, DREYER L, BASLUND B: Increased morbidity from ischemic heart disease in patients with Wegener's granulomatosis. Arthritis Rheum 60: 1187-1192, 2009.

FISCHMAN D, VALLURI A, GORREPATI VS, MURPHY ME, PETERS I, CHERIYATH P: Bilirubin as a protective factor for rheumatoid arthritis: An NHANES study of 2003-2006 data. J Clin Med Res 2: 256-260, 2010.

FULKS M, STOUT RL, DOLAN VF: Mortality associated with bilirubin levels in insurance applicants. $J$ Insur Med 41: 49-53, 2009.

GAZZIN S, VITEK L, WATCHKO J, SHAPIRO SM, TIRIBELLI C: A novel perspective on the biology of bilirubin in health and disease. Trends Mol Med 22: 758-768, 2016.

GHOORAH K, DE SOYZA A, KUNADIAN V: Increased cardiovascular risk in patients with chronic obstructive pulmonary disease and the potential mechanisms linking the two conditions: a review. Cardiol Rev 21: 196-202, 2013.

HANSEN TW, MATHIESEN SB, WALAAS SI: Bilirubin has widespread inhibitory effects on protein phosphorylation. Pediatr Res 39: 1072-1077, 1996.

HINDS TD JR, ADEOSUN SO, ALAMODI AA, STEC DE: Does bilirubin prevent hepatic steatosis through activation of the PPARalpha nuclear receptor? Med Hypotheses 95: 54-57, 2016.

HOKAMAKI J, KAWANO H, YOSHIMURA M, SOEJIMA H, MIYAMOTO S, KAJIWARA I, KOJIMA S, SAKAMOTO T, SUGIYAMA S, HIRAI N, SHIMOMURA H, NAGAYOSHI Y, TSUJITA K, SHIOJI I, SASAKI S, OGAWA H: Urinary biopyrrins levels are elevated in relation to severity of heart failure. $J \mathrm{Am}$ Coll Cardiol 43: 1880-1885, 2004.

HORSFALL LJ, RAIT G, WALTERS K, SWALLOW DM, PEREIRA SP, NAZARETH I, PETERSEN I: Serum bilirubin and risk of respiratory disease and death. J Am Med Assoc 305: 691-697, 2011.

HORSFALL LJ, NAZARETH I, PETERSEN I: Cardiovascular events as a function of serum bilirubin levels in a large, statin-treated cohort. Circulation 126: 2556-2564, 2012.

HORSFALL LJ, NAZARETH I, PEREIRA SP, PETERSEN I: Gilbert's syndrome and the risk of death: a populationbased cohort study. J Gastroenterol Hepatol 28: 1643-1647, 2013.

HWANG HJ, LEE SW, KIM SH: Relationship between bilirubin and C-reactive protein. Clin Chem Lab Med 49: 1823-1828, 2011.

JANGI S, OTTERBEIN L, ROBSON S: The molecular basis for the immunomodulatory activities of unconjugated bilirubin. Int J Biochem Cell Biol 45: 2843-2851, 2013.

JIRASKOVA A, JOVANOVSKA J, SKRHA J, VITEK L: Association of low bilirubin levels and promoter variations in UGT1A1 gene with diabetes mellitus type 2 (abstract). Hepatol Int 5: 37, $2011 \mathrm{a}$.

JIRASKOVA A, JOVANOVSKA J, VITEK L: Association of promoter variation in HMOX1 and UGT1A1 genes with Fabry disease. Clin Biochem 44: S95, 2011 b. 
JIRASKOVA A, NOVOTNY J, NOVOTNY L, VODICKA P, PARDINI B, NACCARATI A, SCHWERTNER HA, HUBACEK JA, PUNCOCHAROVA L, SMERHOVSKY Z, VITEK L: Association of serum bilirubin and promoter variations in HMOX1 and UGT1A1 genes with sporadic colorectal cancer. Int $J$ Cancer 131: 1549-1555, 2012.

KALOUSOVA M, NOVOTNY L, ZIMA T, BRAUN M, VITEK L: Decreased levels of advanced glycation end-products in patients with Gilbert syndrome. Cell Mol Biol 51: 387-392, 2005.

KUNDUR AR, SINGH I, BULMER AC: Bilirubin, platelet activation and heart disease: a missing link to cardiovascular protection in Gilbert's syndrome? Atherosclerosis 239: 73-84, 2015.

KUNUTSOR SK, BAKKER SJ, GANSEVOORT RT, CHOWDHURY R, DULLAART RP: Circulating total bilirubin and risk of incident cardiovascular disease in the general population. Arterioscler Thromb Vasc Biol 35 : 716-724, 2015.

LENICEK M, DURICOVA D, HRADSKY O, DUSATKOVA P, JIRASKOVA A, LUKAS M, NACHTIGAL P, VITEK L: The relationship between serum bilirubin and Crohn's disease. Inflamm Bowel Dis 20: 481-487, 2014.

LEWANDOWSKI LB, KAPLAN MJ: Update on cardiovascular disease in lupus. Curr Opin Rheumatol 28: 468-476, 2016.

LIAO KP: Cardiovascular disease in patients with rheumatoid arthritis. Trends Cardiovasc Med 27: 136-140, 2017.

LIN JP, VITEK L, SCHWERTNER HA: Serum bilirubin and genes controlling bilirubin concentrations as biomarkers for cardiovascular disease. Clin Chem 56: 1535-1543, 2010.

LIU CS, HSU HS, LI CI, JAN CI, LI TC, LIN WY, LIN T, CHEN YC, LEE CC, LIN CC: Central obesity and atherogenic dyslipidemia in metabolic syndrome are associated with increased risk for colorectal adenoma in a Chinese population. BMC Gastroenterol 10: 51, 2010.

MARUHASHI T, SOGA J, FUJIMURA N, IDEI N, MIKAMI S, IWAMOTO Y, KAJIKAWA M, MATSUMOTO T, KIHARA Y, CHAYAMA K, NOMA K, NAKASHIMA A, TOMIYAMA H, TAKASE B, YAMASHINA A, HIGASHI Y: Hyperbilirubinemia, augmentation of endothelial function and decrease in oxidative stress in Gilbert syndrome. Circulation 126: 289-297, 2012.

MCCARTY MF: "Iatrogenic Gilbert syndrome" - a strategy for reducing vascular and cancer risk by increasing plasma unconjugated bilirubin. Med Hypotheses 69: 974-994, 2007.

MCDONALD SD, RAY J, TEO K, JUNG H, SALEHIAN O, YUSUF S, LONN E: Measures of cardiovascular risk and subclinical atherosclerosis in a cohort of women with a remote history of preeclampsia. Atherosclerosis 229: 234-239, 2013.

MIANOWSKA B, KAMINSKA A, FENDLER W, SZADKOWSKA A, MLYNARSKI W: Bilirubin is an independent factor inversely associated with glycated hemoglobin level in pediatric patients with type 1 diabetes. Pediatr Diabetes 15: 389-393, 2014.

MOLZER C, HUBER H, STEYRER A, ZIESEL GV, WALLNER M, HONG HT, BLANCHFIELD JT, BULMER AC, WAGNER KH: Bilirubin and related tetrapyrroles inhibit food-borne mutagenesis: a mechanism for antigenotoxic action against a model epoxide. J Nat Prod 76: 1958-1965, 2013.

MUCHOVA L, WONG RJ, HSU M, MORIOKA I, VITEK L, ZELENKA J, SCHRODER H, STEVENSON DK: Statin treatment increases formation of carbon monoxide and bilirubin in mice: a novel mechanism of in vivo antioxidant protection. Can J Physiol Pharmacol 85: 800-810, 2007.

NANO J, MUKA T, CEPEDA M, VOORTMAN T, DHANA K, BRAHIMAJ A, DEHGHAN A, FRANCO OH: Association of circulating total bilirubin with the metabolic syndrome and type 2 diabetes: a systematic review and meta-analysis of observational evidence. Diabetes Metab 42: 389-397, 2016.

NOVOTNY L, VITEK L: Inverse relationship between serum bilirubin and atherosclerosis in men: a meta-analysis of published studies. Exp Biol Med 228: 568-571, 2003.

ONG KL, ALLISON MA, CHEUNG BM, WU BJ, BARTER PJ, RYE KA: The relationship between total bilirubin levels and total mortality in older adults: the United States National Health and Nutrition Examination Survey (NHANES) 1999-2004. PLoS One 9: e94479, 2014.

ONISHI S, YAMAKAWA T, OGAWA J: Photochemical and photobiological studies on the light-treated newborn infant. Perinatology 1: 373-379, 1971. 
PENG F, DENG X, YU Y, CHEN X, SHEN L, ZHONG X, QIU W, JIANG Y, ZHANG J, HU X: Serum bilirubin concentrations and multiple sclerosis. J Clin Neurosci 18: 1355-1359, 2011.

PEPPA M, URIBARRI J, VLASSARA H: The role of advanced glycation end products in the development of atherosclerosis. Curr Diab Rep 4: 31-36, 2004.

PERLSTEIN TS, PANDE RL, BECKMAN JA, CREAGER MA: Serum total bilirubin level and prevalent lowerextremity peripheral arterial disease - National Health and Nutrition Examination Survey (NHANES) 1999 to 2004. Arterioscler Thromb Vasc Biol 28: 166-172, 2008.

SCHWERTNER HA, JACKSON WG, TOLAN G: Association of low serum concentration of bilirubin with increased risk of coronary artery disease. Clin Chem 40: 18-23, 1994.

SCHWERTNER HA, VITEK L: Low serum bilirubin concentrations and risk of rheumatoid arthritis and lupus nephropathy. Clin Chem 50: A53, 2004.

SCHWERTNER HA, VITEK L: Gilbert syndrome, UGT1A1*28 allele, and cardiovascular disease risk: possible protective effects and therapeutic applications of bilirubin. Atherosclerosis 198: 1-11, 2008.

STEC DE, JOHN K, TRABBIC CJ, LUNIWAL A, HANKINS MW, BAUM J, HINDS TD JR: Bilirubin binding to PPARalpha inhibits lipid accumulation. PLoS One 11: e0153427, 2016.

STENDER S, FRIKKE-SCHMIDT R, NORDESTGAARD BG, GRANDE P, TYBJAERG-HANSEN A: Genetically elevated bilirubin and risk of ischaemic heart disease: three Mendelian randomization studies and a metaanalysis. J Intern Med 273: 59-68, 2013.

STOCKER R, YAMAMOTO Y, MCDONAGH AF, GLAZER AN, AMES BN: Bilirubin is an antioxidant of possible physiological importance. Science 235: 1043-1046, 1987.

STRASKY Z, ZEMANKOVA L, NEMECKOVA I, RATHOUSKA J, WONG RJ, MUCHOVA L, SUBHANOVA I, VANIKOVA J, VANOVA K, VITEK L, NACHTIGAL P: Spirulina platensis and phycocyanobilin activate atheroprotective heme oxygenase-1: a possible implication for atherogenesis. Food Funct 4: 1586-1594, 2013.

TURK Z, SESTO M, SKODLAR J, FERENCAK G, POKUPEC R, TURK N, STAVLJENIC-RUKAVINA A: Products of advanced glycation in patients with type 2 diabetes and vascular disease. Ann Clin Biochem 40: 552-559, 2003.

VEJUX A, LIZARD G: Cytotoxic effects of oxysterols associated with human diseases: Induction of cell death (apoptosis and/or oncosis), oxidative and inflammatory activities, and phospholipidosis. Mol Aspects Med 30: 153-170, 2009.

VITEK L: The role of bilirubin in diabetes, metabolic syndrome, and cardiovascular diseases. Front Pharmacol 3: 55, 2012.

VITEK L, HALUZIK M: The role of bile acids in metabolic regulation. J Endocrinol 228: R85-R96, 2016.

VITEK L, OSTROW JD: Bilirubin chemistry and metabolism; harmful and protective aspects. Curr Pharm Des 15 : 2869-2883, 2009.

VITEK L, SCHWERTNER HA: The heme catabolic pathway and its protective effects on oxidative stress-mediated diseases. Adv Clin Chem 43: 1-57, 2007.

VITEK L, JIRSA M, BRODANOVA M, KALAB M, MARECEK Z, DANZIG V, NOVOTNY L, KOTAL P: Gilbert syndrome and ischemic heart disease: a protective effect of elevated bilirubin levels. Atherosclerosis 160: 449-456, 2002.

VITEK L, NOVOTNY L, SPERL M, HOLAJ R, SPACIL J: The inverse association of elevated serum bilirubin levels with subclinical carotid atherosclerosis. Cerebrovasc Dis 21: 408-414, 2006.

VITEK L, KRASLOVA I, MUCHOVA L, NOVOTNY L, YAMAGUCHI T: Urinary excretion of oxidative metabolites of bilirubin in subjects with Gilbert syndrome. J Gastroenterol Hepatol 22: 841-845, 2007a.

VITEK L, MALIKOVA I, KVASNICKA J, BENAKOVA H, NOVOTNY L: Relationship between serum bilirubin and markers of inflammation and oxidative stress. J Gastroenterol Hepatol 22: A235, 2007b.

VITEK L, MUCHOVA L, JANCOVA E, PESICKOVA S, TEGZOVA D, PETEROVA V, PAVELKA K, TESAR V: Association of systemic lupus erythematosus with low serum bilirubin levels. Scand J Rheumatol 39: 480-484, 2010a.

VITEK L, NOVOTNA M, LENICEK M, NOVOTNY L, EBEROVA J, PETRASEK J, JIRSA M: Serum bilirubin levels and UGT1A1 promoter variations in patients with schizophrenia. Psychiatry Res 178: 449-450, 2010b. 
VITEK L, MUCHOVA L, ZAK A: Statin use and serum bilirubin levels. Atherosclerosis 219: 969, 2011.

VITEK L, NOVOTNY L, ZAK A, STANKOVA B, ZIMA T, POLITO A, CESARE G, ZERBINATI C, IULIANO L: Relationship between serum bilirubin and uric acid to oxidative stress markers in Italian and Czech populations. J Appl Biomed 11: 209-221, 2013.

WAGNER KH, WALLNER M, MOLZER C, GAZZIN S, BULMER AC, TIRIBELLI C, VITEK L: Looking to the horizon: the role of bilirubin in the development and prevention of age-related chronic diseases. Clin Sci (Lond) 129: 1-25, 2015.

WALLNER M, ANTL N, RITTMANNSBERGER B, SCHREIDL S, NAJAFI K, MULLNER E, MOLZER C, FERK F, KNASMULLER S, MARCULESCU R, DOBERER D, POULSEN HE, VITEK L, BULMER AC, WAGNER KH: Anti-genotoxic potential of bilirubin in vivo: damage to DNA in hyperbilirubinemic human and animal models. Cancer Prev Res (Phila) 6: 1056-1063, 2013a.

WALLNER M, MARCULESCU R, DOBERER D, WOLZT M, WAGNER O, VITEK L, BULMER AC, WAGNER KH: Protection from age-related increase in lipid biomarkers and inflammation contributes to cardiovascular protection in Gilbert's syndrome. Clin Sci 125: 257-264, 2013 b.

WU TW, FUNG KP, YANG CC: Unconjugated bilirubin inhibits the oxidation of human low density lipoprotein better than Trolox. Life Sci 54: 477-481, 1994.

WU GC, LENG RX, LU Q, FAN YG, WANG DG, YE DQ: Subclinical atherosclerosis in patients with inflammatory bowel diseases: a systematic review and meta-analysis. Angiology in press 2016.

ZARATE YA, HOPKIN RJ: Fabry's disease. Lancet 372: 1427-1435, 2008. 